\title{
Peran PAK Dalam Membentuk Mental Positif Generasi Kristen Di Era Millenial
}

\author{
Ya'aman Gulo, ${ }^{* 1}$ Rita Evimalinda, ${ }^{2}$ Ardianto Lahagu ${ }^{3}$ \\ Prodi PAK, STT Real Batam \\ Prodi PAK, STT Real Batam \\ yamn.gulo@gmail.com
}

\begin{abstract}
This research departs from the author's observation of the progress of the current era. The progress of the current era does not necessarily have a positive impact on the younger generation, especially the Christian generation. There are many young people today who fall into sin as a result of the progress of this age. To overcome these problems requires a positive mentality from every Christian generation. So Christian religious education has an important role in this matter so that through Christian religious education, our young generation is able to face the bad influence of the progress of this age. The research method used in this paper is a qualitative method. The author collects data from various sources of literature which are then analyzed objectively and concluded in a descriptive form. The data sources in this study are the Bible, books, journals, and other literature obtained from the internet. The results obtained in this study indicate that there are still young generations of Christians who do not have a strong mentality to face the progress of this age. Therefore, Christian Religious Education is needed in shaping the positive mentality of the Christian generation because a strong positive mentality determines their future. The purpose of this paper is the first is to find out the role of Christian religious education in shaping positive mental millennial generation, the second is to find out the challenges of Christian religious education in the millennial era, and the third is to find out how Christian religious education in shaping positive mental generation millennial.
\end{abstract}

Keywords: Role, Christian Religious Education, Mental, Generation, Millennial

\begin{abstract}
Abstrak
Penelitian ini berangkat dari observasi penulis terhadap kemajuan zaman saat ini. Kemajuan zaman saat ini tidak serta merta membawa dampak yang positif bagi generasi muda khususnya generasi Kristen. Ada banyak generasi muda saat ini yang jatuh ke dalam dosa akibat dari kemajuan zaman ini. Untuk mengatasi masalah tersebut dibutuhkan mental positif dari setiap generasi Kristen. Maka pendidikan agama Kristen memiliki peran penting dalam hal ini sehingga melalui pendidikan agama Kristen, generasi muda kita mampu menghadapi pengaruh buruk dari kemajuan zaman ini. Metode penelitian yang digunakan dalam tulisan ini adalah metode kualitatif. Penulis mengumpulkan data dari berbagai sumber literature yang kemudian dianalisis secara objektif dan disimpulkan dalam bentuk deskriptif. Adapun sumber data dalam penelitian ini adalah Alkitab, buku, jurnal, serta literature lain yang didapat dari internet. Hasil yang didapat dalam penelitian ini menunjukkan bahwa masih ada generasi muda Kristen yang belum memiliki mental yang kuat untuk menghadapi kemajuan zaman ini. Oleh karenanya, Pendidikan Agama Kristen sangat dibutuhkan dalam membentuk mental positif generasi Kristen karena mental positif yang kuat menentukan masa depan mereka. Adapun tujuan dari tulisan ini adalah yang pertama adalah untuk mengetahui peran pendidikan Agama Kristen dalam membentuk mental positif generasi millenial, yang kedua adalah untuk mengetahui tantangan pendidikan agama Kristen di era
\end{abstract}


millennial, dan yang ketiga adalah untuk mengetahui cara pendidikan agama Kristen dalam membentuk mental positif generasi millenial.

Kata kunci: Peran, PAK, Mental, Generasi, Millenial

\section{PENDAHULUAN}

Tulisan ini dimulai dari observasi penulis terhadap kemajuan zaman saat ini. Ada banyak masalah yang terjadi akibat kemajuan zaman ini, khususnya bagi kalangan anak anak muda Kristen,seperti hamil di luar nikah akibat pacaran yang berlebihan, kencanduan porno grafi, narkoba, minuman keras, dan sebagainya. Hal ini terjadi karena mental mereka tidak siap untuk menghadapi berbagai tantangan yang ada di zaman ini. Maka, berangkat dari masalah tersebut, penulis merasa bahwa diperlukan upaya untuk mencegah masalah tersebut.

Untuk menghadapi kemajuan zaman dan teknologi saat ini diperlukan mental yang kuat dan positif dari setiap generasi Kristen supaya generasi ini tidak jatuh dalam keburukan zaman ini. Dengan demikian, Pendidikan Agama Kristen memiliki peran penting dalam mengupayakan pencegahan atas masalah - masalah ini. Jika masalah ini terus dibiarkan maka, anak - anak muda Kristen akan mengalami keburukan moral, hidup yang tidak jelas, serta masa depan yang suram. Oleh karenanya, mental anak - anak muda saat ini harus diperbaiki dan dibentuk kembali melalui nilai - nilai kebenaran dengan dasar yang kokoh yaitu Firman Tuhan atau Alkitab.

Dari masalah yang sudah dijelaskan di atas, penulis menemukan beberapa pertanyaan untuk dibahas dalam tulisan ini, yang pertama adalah sudahkah Pendidikan Agama Kristen siap menghadapi tantangan Era Millenial? Yang kedua adalah apa peran Pendidikan Agama Kristen dalam membentuk Mental anak - anak muda Kristiani di era Millenial? Yang ketiga bagaimana cara Pendidikan Agama Kristen dalam membentuk Mental Positif generasi Kristen masa kini?

Maka melalui tulisan ini, penulis ingin menjelaskan peran Pendidikan Agama Kristen dalam Membentuk Mental Positif Generasi Kristen di zaman ini. Dan melalui tulisan ini, lembaga - lembaga, serta guru - guru Pendidikan Agama Kristen semakin mengerti panggilan dan perannya di zaman ini, karena ini merupakan masalah yang serius oleh karenanya harus ditanggapi dengan serius.

\section{METODE}

Metode penelitian yang digunakan dalam tulisan ini adalah metode kualitatif. Penulis mengumpulkan data dari berbagai sumber literature yang kemudian dianalisis secara objektif dan disimpulkan dalam bentuk deskriptif. Adapun sumber data dalam penelitian ini adalah Alkitab, buku, jurnal, serta literature lain yang didapat dari internet. 


\section{HASIL DAN PEMBAHASAN}

\section{Tantangan Pendidikan Agama Kristen Di Era Millenial \\ Penyalahgunaan Kecanggihan Teknologi}

Penyalahgunaan teknologi merupakan salah satu tantangan pendidikan saat ini. Jika penggunaan teknologi tidak dipakai dengan tepat maka akan berakibat fatal. Putu Agus dan Gusti Lanang mengatakan bahwa "Resiko kemungkinan penyalahgunaan teknologi yang dapat mengakibatkan kerugian yang bahkan tidak terbayangkan. Resiko tersebut dapat berupa ancaman fisik seperti pencurian dan penghacuran aset."

Bisa kita bayangkan jika resiko tersebut di atas terjadi pada generasi muda, maka akan mengakibatkan kerugian besar, bukan hanya orang lain yang dirugikan tetapi juga dirinya sendiri dan lembaga pendidikan yang mendidiknya. Oleh karena itu, pendidikan agama Kristen harus bisa menghadapi tantangan ini, supaya generasi muda tidak terlibat dalam kasus tersebut. Pendidikan agama Kristen harus berperan aktif untuk membentuk generasi yang berkarakter dan bermoral, sehingga generasi millennial mampu menguasai diri dalam hal menggunakan atau memanfaatkan kemajuan teknologi ini.

\section{Pergaulan Bebas}

Kemajuan zaman saat ini banyak membawa perubahan, baik itu budaya, gaya hidup, kebutuhan, dan sebagainya. Kemajuan zaman harusnya membawa dampak yang baik bagi masyarakat. Namun, kenyataan yang kita lihat saat ini ada banyak dampak negatif yang diakibatkan oleh perkembangan zaman saat ini. Salah satunya adalah pergaulan bebas. Generasi millennial sangat rentan dengan kondisi ini. Mereka menjadikan hal ini sebagai budaya dan gaya hidup mereka, seperti pacaran yang mengakibatkan hamil di luar nikah, narkoba, miras, dan sebagainya.

Menurut data BKKBN (Badan Kependudukan dan Keluarga Berencana Nasional) tahun 2010, pergaulan bebas di Indonesia sering terjadi di kota-kota besar, seperti JABODETABEK. Di JABODETABEK sendiri didapatkan bahwa 51\% remaja telah hilang keperawanannya. Sedangkan di kota lain seperti Surabaya 54\%, Medan 52\%, Bandung 47\%, dan Yogyakarta 42\%. Jika dilihat dari data tersebut jelas hal ini menyedihkan. Muncul pertanyaan bagi kita, mengapa hal ini bisa terjadi dan apa penyebabnya.

Dari hasi penelitian BKKBN ada beberapa faktor penyebab terjadinya pergaulan bebas, namun penulis hanya mengambil tiga faktor utama, yaitu

1. kurangnya pegangan hidup remaja dalam hal keyakinan/Agama

2. Sikap mental yang tidak sehat

3. Pola pikir yang salah

\footnotetext{
${ }^{1}$ Putu Agus Swastika and Gusti Lanang Agung Raditya Putra, Audit Sistem Informasi Dan Tata Kelola Teknologi Informasi (Yogyakarta: Andi Offset, 2016).21
} 
Dari tiga faktor utama tersebut, disitu bisa kita lihat bahwa peran pendidikan iman dan karakter atau pendidikan agama sangat dibutuhkan. Pendidikan agama khususnya pendidikan agama Kristen harus membuka mata terhadap masalah yang terjadi dikalangan generasi millennial saat ini. Pendidikan harus mampu memberi solusi dari ketiga faktor utama tersebut di atas. Menurut penulis, Jika tidak dilakukan upaya pencegahan dari masalah tersebut, maka jangan heran jika generasi millennial bangsa kita akan diperbudak oleh kemajuan zaman itu sendiri.

Oleh karena itu, sudah menjadi tugas dan sekaligus menjadi tantangan bagi pendidikan agama Kristen untuk membentuk generasi yang memiliki karakter dan tanggungjawab. Pendidikan agama Kristen harus memberikan perhatian yang serius terhadap generasi saat ini. Pendidikan agama Kristen harus bisa mendidik generasi millennial yang memiliki peganngan hidup dan takut akan Tuhan, membentuk mental positif, serta membentuk pola pikir yang sehat, sehingga generasi millennial kita menjadi generasi yang bertanggung jawab dan memiliki masa depan yang cerah.

\section{Peran Pendidikan Agama Kristen Di Era Millenial Membentuk Kerohanian}

Salah satu peran pendidikan agama Kristen adalah membentuk kerohanian manusia. Andar ismail mengatakan "Anak-anak yang akan hidup sebagai orang dewasa di abad ke 21 membutuhkan iman dan kepribadian Kristen yang dapat menghadapi dunia globalisasi."2 Oleh karena itu peran pendidikan agama Kristen sangat penting untuk mendidik generasi millenial supaya tetap hidup dalam kebenaran. Menurut penulis, Iman dan kepribadian yang takut akan Tuhan merupakan senjata bagi anak millennial dalam menghadapi perkembangan zaman saat ini. Maka pendidikan agama Kristen harus bisa mendidik generasi millennial untuk memiliki iman yang teguh kepada Kristus supaya tidak terpengaruh oleh keburukan zaman saat ini.

\section{Membentuk Karakter}

Seiring perkembangan zaman ada banyak generasi muda yang kehilangan moral atau karakter. Handreas Hartono mengatakan bahwa"melihat perkembangan zaman yang ditandai dengan berkembangnya teknologi dan gaya hidup, ternyata turut merubah karakter anak-anak Kristen. Teknologi adalah sesuatu yang positif jika digunakan sesuai dengan fungsinya, tetapi akan menjadi negative jika digunakan tanpa memperhatikan batasanbatasan normative. Bayangkan saja pada anak yang berusia satu tahun yang menghabiskan waktunya sekian jam dalam sehari di depan televisi untuk menonton film kartun kesukaanya. Anak-anak sekolah dasar lebih banyak menghabiskan waktunya untuk bermain game dari pada belajar, bahkan anak-anak ini akan mengalami stress yang tinggi

${ }^{2}$ Andra Ismail, Ajarlah Mereka Melakukan : Kumpulan Karangan Seputar Pendidikan Agama Kristen (Jakarta: BPK Gunung Mulia, 1998).132 
jika akses internet di rumahnya terganggu. Gaya hidup serba instan juga telah merubah karakter seorang anak. Dia tidak melihat lagi sesuatu berdasarkan proses, tetapi lebih melihat segala sesuatu dari hasil akhir."

Dari penjelasan diatas dapat kita bayangkan betapa bahayanya kemajuan teknologi jika tidak digunakan dengan baik. Hal ini bisa saja membawa krisis moral bagi generasi masa kini. Maka dibutuhkan peran dari Pendidikan Agama Kristen untuk membangun karakter generasi millennial. Oleh karenanya, Arozatulo Telaumbanua menegaskan peranan guru Pendidikan Agama Kristen dalam membentuk karakter generasi millennial. Dalam tulisanya mengatakan bahwa"seorang guru Pendidikan Agama Kristen tidak boleh mengabaikan peranannya sebagai guru yang memiliki tanggungjawab membentuk karakter siswanya. Artinya, guru Pendidikan Agama Kristen tidak hanya sekedar mengajar, melainkan memberikan kontribusi yang sangat berharga lebih dari sekedar mengajar, yakni berusaha membentuk karakter siswa. Dua hal ini tidak dapat dikotak-kotakkan antara peranan guru dengan karakter. Guru Kristen dapat berarti yang mengajar prinsip dan praktis iman Kristen, atau guru yang beragama Kristen yang mengajar pelajaran apa saja, namun fokus utamanya adalah pembentukan karakter." ${ }^{4}$

Dari asumsi tersebut di atas memberikan gambaran bagi kita bahwa kemajuan zaman saat ini berpotensi membawa krisis moral dalam kehidupan generasi millennial. Oleh karenanya peran Pendidikan Agama Kristen sangat dibutuhkan untuk membentuk karakter generasi millennial saat ini. Pendidikan Agama Kristen harus membangun karakter anak muda atas dasar iman kepada Yesus Kristus, sehingga masalah krisis moral ini bisa diatasi.

\section{Pemuridan}

Pendidikan agama Kristen tidak cukup hanya mentransfer ilmu pengetahuan, tetapi juga memuridkan. Generasi millennial harus dimuridkan supaya mereka tetap terkontrol dan memiliki pengenalan yang lebih tentang Allah dan hukuman atas dosa yang dilakukannya. Dengan adanya pemuridan ini, generasi millennial memiliki pemahaman yang benar tentang dosa dan mampu menguasai diri untuk menggunakan alat teknologi dengan benar.

Menurut Doug Hartman, "ketika seorang murid belajar untuk menyandarkan diri pada Firman Allah dan tidak membiarkan dirinya dikuasai oleh pengalaman-pengalaman negative yang ada disekelilingnya, sikapnya secara lambat laun berubah dari negative ke sikap positif. Ini karena Firman Allah yang bersifat positif."

\footnotetext{
${ }^{3}$ Handreas Hartono, "Membentuk Karakter Kristen Pada Anak Keluarga Kristen,” Kurios 2, no. 1 (2014): 62-69. 62-63

${ }^{4}$ Arozatulo Telaumbanua, "Peranan Guru Pendidikan Agama Kristen Dalam Membentuk Karakter Siswa," Fidei 1, no. 2 (2018): 219-231. 221

${ }^{5}$ Dough Hartman, Murid Yang Berlipat Ganda (Malang: Gandum Mas, 1991).13
} 
Dari pendapat di atas bisa kita ketahui bahwa pemuridan sangat penting bagi generasi millennial saat ini, karena melalui pemuridan ini generasi millennial bisa menghadapi pengaruh negative dari kemajuan zaman saat ini. Dan bukan hanya itu saja, melalui pemuridan ini juga, generasi millennial, dapat mengubah pola pikir dan sikap, sehingga sikap individual yang terdapat dalam diri generasi millenial dapat terminimalisir. ${ }^{6}$

\section{Pentingnya PAK dalam Membentuk Mental Positif Generasi Kristen}

Di zaman millennial ini, mental positif sangat perlu untuk ditumbuhkan dalam diri setiap gerenasi muda, khususnya generasi Kristen. Bagaimana tidak, di zaman sekarang ini ada banyak penyalahgunaan teknologi dikalangan remaja misalnya saja kecanduan game online. Contoh kasus, ada sepuluh anak di Banyumas yang mengalami kecanduan game online. Kesepuluh anak tersebut telah didiagnosa mengalami gangguan mental. Menurut pengakuan Hilma Paramita dokter Spesialis Jiwa RSUD Banyumas, mengatakan rata - rata pasien sudah tidak bisa mengendalikan diri bermain game online. Akibatnya, mereka sudah tidak bisa beraktivitas dengan normal. ${ }^{7}$

Kemudian kasus pornografi semakin merajalela. Contohnya ada salah satu siswa yang ditangkap oleh Satreskrim Polres di Ponorogo, lantaran diduga menyebarkan video setengah bugil siswi SLTA di Kabupaten Ponorogo. CAP diketahui merupakan kekasih siswi yang ada di video tersebut. "Pelaku ditangkap petugas di rumah saudaranya di Gresik," kata Kapolres Ponorogo, AKBP Radiant saat jumpa pers, Senin (22/7/2019). Kapolres menuturkan pelaku merupakan kekasih siswi dalam video asusila yang tersebar melalui aplikasi perpesanan Whatsapp. Siswi itu berinisial TPN, 16, warga Ponorogo. Dari pengakuannya telah melakulan hubungan suami istri dengan TPN beberapa kali. Pertama kali berhubungan badan dilakukan di rumah pelaku pada 2017. Selanjutnya kedua sejoli itu kembali melakukan hubungan suami istri di salah satu hotel kawasan Ngebel pada Februari dan Juni 2019. Radiant menuturkan video tersebut disebarkan karena TPN tidak mau lagi diajak berhubungan intim. ${ }^{8}$

Kemudian menurut penelitian AAP (Amerika Association of Pediatrics), yang dikutip oleh Gusti Restu Kinanti dalam tulisannya, mengatakan bahwa "kini anak - anak menghabiskan rata - rata tujuh jam sehari untuk menggunakan media, termasuk televisi, computer, telepon, dan alat elektronik lain."

Dari beberapa kasus di atas, kita dapat mengetahui bahwa perkembangan zaman juga membawa pengaruh buruk bagi generasi millennial. Oleh karena itu, peran guru

\footnotetext{
${ }^{6}$ Agustina Allo, "Implementasi Pemuridan Sebagai Misi Terhadap Generasi Milenial Pada Zaman Modern" (Institut Agama Kristen Negeri Toraja, 2020).

${ }^{7}$ Ray, "Kecanduan Game Online, 10 Anak Di Banyumas Alami Gangguan Mental," Merdeka.Com.

${ }^{8}$ Talizaro Tafonao, "Peran Guru Dalam Menangani Perilaku Menyimpang Di Kalangan Siswa Millenial" (STT KADESI, 2019). 27

${ }^{9}$ Gusti Restu Kinanti, "Memahami Relasi Komunikasi Orang Tua Milenial Dalam Pembentukan Konsep Diri Anak Di Era Digital,” 2019. 2
} 
pendidikan agama Kristen sangat berpengaruh bagi kaum millennial saat ini. Talizaro mengatakan bahwa

'guru tidak hanya dituntut menjadi guru yang professional dengan segala upaya dapat menguasai kurikulum, menguasai materi yang diajarkan, terampil menggunakan multi metode pembelajaran, mempunyai perilaku yang baik, memiliki kedisiplinan dalam arti yang seluas - luasnya dan mampu berkomunikasi. Tetapi, guru juga dituntut untuk dapat menangani berbagai perilaku menyimpang di kalangan generasi millennial tersebut. ${ }^{10}$

Dari gagasan tersebut dapat kita ketahui bahwa tugas guru sangat penting di era millennial ini. Guru tidak hanya sebagai pengajar yang hanya sekedar memberikan ilmu pengetahuan, tetapi guru juga berperan sebagai pembimbing dan pendidik, Talizaro mengistilahkannya dengan "orang tua kedua bagi generasi muda."11 Melalui bimbingan guru pendidikan agama Kristen ini diharapkan bisa memberi dampak bagi kehidupan generasi millennial, yaitu membentuk mental positif generasi millennial supaya bisa memanfaatkan kemajuan teknologi ini untuk hal - hal yang baik dan berguna bagi masa depan yang cerah.

\section{Mental Positif untuk Masa Depan yang Sukses}

Masa depan tidak terlepas dari yang namanya mental positif. Mental positif artinya adalah sikap mental psikologis yang membangkitkan rasa ingin berhasil lewat sifat optimistic. ${ }^{12}$ Menurut penulis, hal ini jelas bahwa sikap mental yang kuat akan berdampak pada keberhasilan seseorang. Sikap mental yang positif ini akan diperoleh melalui sifat opstimistik, artinya memiliki pola pikir yang baik, mau maju, dan mau berhasil.

Menurut data yang diperoleh dari jurnal Mozaik, Vol. X edisi 2 mengatakan bahwa "Indonesia yang penduduknya tercatat lebih dari 250 juta, diperkirakan sepertiganya yaitu kira - kira 80 jutaan berusia 17 - 37 tahun yang dapat dikategorikan sebagai generasi millennial. Melihat begitu besar jumlah generasi muda Indonesia berarti bangsa ini berpeluang memiliki potensi yang besar untuk membangun negaranya. Namun fakta yang menyedihkan akibat pengaruh budaya global generasi millennial justru menghabiskan waktunya dengan menyaksikan tayangan - tanyangan budaya bangsa lain yang tidak normative, padahal kejayaan Indonesia terletak ditangan mereka para millennial, sebagaimana masyarakat Indonesia memiliki beranekaragam budaya yang terbentang di seluruh Nusantara." 13

\footnotetext{
${ }^{10}$ Tafonao, "Peran Guru Dalam Menangani Perilaku Menyimpang Di Kalangan Siswa Millenial.”167

${ }^{11}$ Ibid. 167

${ }^{12}$ Doni Rahman, "Project Management," Kinibisa.

${ }^{13}$ Nurlaila Suci Rahayu Rais, M Malik Jovian Dien, and Albert Y Dien, "Kemajuan Teknologi Informasi Berdampak Pada Generalisasi Unsur Sosial Budaya Bagi Generasi Milenial,” Jurnal Mozaik 10, no. 2 (2018): 6171.66
} 
Jadi, dari data di atas dapat kita lihat bahwa generasi millennial memegang peranan penting bagi kemajuan bangsa ini. Menurut Jeane Marie Tulung, dkk mengatakan bahwa "nasib bangsa ini tergantung pada mereka (millennial) ${ }^{14}$, namun jika generasi millennial itu sendiri yang merusak moral bangsa ini, tidak mau maju, dan tidak mau membangun, maka mau dibawa kemana bangsa ini. Oleh karena itu, setiap generasi muda harus memiliki mental positif, artinya jangan mau diperbudak oleh kemajuan teknologi, tetapi manfaatkanlah teknologi itu untuk membangun masa depan yang sukses serta membangun bangsa dan negara.

\section{KESIMPULAN}

Pemerintahan bukan sesuatu yang buruk bila dipahami sebagai anugerah Allah. Dimana kekuasan yang ada berasal dari Allah dan bertujuan untuk mendatangkan kebaikan bagi masyarakat. Jabatan dan kekuasaan itu dipandang sebagai kesempatan untuk mengabdi kepada kepada Tuhan. Setiap orang Kristen semestinya tunduk kepada pemerintah karena pemerintah merupakan hamba Allah. Pemahaman bahwa pemerintahan itu ada karena ketetapan Allah dan mereka menjadi hamba Allah untuk menjalankan roda kepemimpinan yang ada di dunia.

Orang yang percaya kepada Allah melihat keterlibatan dalam politik praktis sebagai bentuk pelayanan kepada Allah. Adanya panggilan sebagai politikus Kristen dimana menempatkan dirinya dipakai Allah sebagai penerima kekuasaan. Kehadirannya di pemerintahan untuk mewujudkan kerinduan Allah dalam menyatakan Injil.

\section{KEPUSTAKAAN}

Boiliu, Noh Ibrahim. "Etika Teologi Politik: Analisis Etis Teologis Ketaatan Kepada Pemerintah." Journal of Chemical Information and Modeling 8, no. 9 (2017): 1-58. Budiadjo, Miriam. Dasar-Dasar Ilmu Politik. Jakarta: Gramedia, 2008.

Edwin, Paskalis, and I Nyoman Paska. "Haruskah Kita Takluk Kepada Pemerintah?" (n.d.): $1-7$.

Fransiska, Ni Nyoman. "Entitas Gereja Dalam Berpolitik Di Indonesia (Tinjauan Sudut Etika Kristen)." Journal of Chemical Information and Modeling 53, no. 9 (2019): 1689-1699.

Guthrie, Donald. Teologi Perjanjian Baru I. Jakarta: BPK Gunung Mulia, 2008.

Marcus Borg. A New Context for Romans XIII," New Testament Studies. Michigan: W. B. Eerdmans Publishing Company, 1976.

Philipus, Ng. Sosiologi Dan Politik, n.d.

Pranoto, Minggus Minarto. "Relasi Gereja Dengan Negara." Amanat Agung 5 (2009).

Sianipar, Ronald. "Hubungan Partisipasi Umat Kristen Dalam Dunia Politik Dan

Pendidikan Terhadap Mandat Amanat Agung." Real Didache 4, no. 1 (2019): 58-68.

Simamora, Adolf Bastian. "Gereja Dalam Pusaran Politik Di Indonesia" (2019).

Wahono, S. Wismoady. Disini Kutemukan. Jakarta: BPK Gunung Mulia, 2004.

${ }^{14}$ Achmad Syahid et al., "Generasi Milenial : Diskursus Teologi, Pendidikan, Dinamika Psikologis Dan Kelekatan Pada Agama Di Era Banjir Informasi,” 2019.7 
Widjaja, Fransiskus Irwan. "Peran Gereja Terhadap Kehidupan Politik Di Wilayah Kepulauan Riau." Real Didache 1, no. 2 (2016): 117-140.

Alkitab Edisi Studi. Bogor: Lembaga Alkitab Indonesia, 2011.

"Wikipedia," n.d. 